\title{
Igreja e Missão no contexto de Pós-modernidade
}

\author{
Church and Mission in the context \\ of postmodernism
}

Paulo Sérgio Lopes Gonçalves

\section{Resumo}

Objetiva-se neste trabalho analisar teologicamente a missão da Igreja no contexto de pós-modernidade. Justifica-se este objetivo pelo fato de que a tradição cristã evidencia que a Igreja, ao se fundar na Trindade, assume a identidade de koinonia, tanto em sua estrutura interna quanto na sua relação com o homem situado na sua contemporaneidade histórica. Em sua intimidade com a Trindade, a Igreja é comunhão e missão ou até mesmo comunhão missionária, situando-se no mundo e em um espírito de diálogo. Anuncia e testemunha o evangelho, sempre de modo que ele seja atual aos seres humanos. Para atingir este objetivo, apresentar-se-á o status quaestionis, expor-se-ão os conceitos fundamentais - Igreja, missão e pós-modernidade para se apresentar a missão da Igreja, concebida como evangelização em cada época histórica, o ecumenismo e o diálogo interreligioso e a dimensão social da evangelização. Por fim, conclui-se sintetizando os pontos fundamentais desenvolvidos ao longo do artigo e exortando à efetividade da espiritualidade evangelizadora.

Palavras-chaves: Igreja. Missão. Pós-modernidade. Evangelização. Diálogo.

\section{Abstract}

In this study aims at analyzing theologically the Church's mission in the context of Postmodernity. This objective justified the fact that Christian 
tradition shows that the Church is founded on Trinity, assumes the identity of koinonia, both in your internal structure and in your relationship with the man situated in your contemporary history. In your intimacy with the Trinity, the Church's communion and mission or even missionary communion, standing in the world and in a spirit of dialogue, announces and witness the Gospel, so that it is current to humans. To achieve this goal, will present the status quaestionis, will expose the fundamental concepts - Church, mission and Postmodernity - to present the Mission of the Church, meant as evangelization in every historical era, ecumenism and interreligious dialogue and the social dimension of evangelisation. Finally, to sum up the key points developed throughout the article and urging the effectiveness of evangelizing spirituality.

Keywords: Church. Mission. Postmodernity. Evangelism. Dialogue.

\section{Introdução}

Objetiva-se neste trabalho analisar teologicamente a missão da Igreja na era contemporânea, em sua condição de pós-modernidade globalizada. Justifica-se este objetivo pelo fato de que a tradição cristã evidencia que a Igreja se funda na Trindade, cuja identidade é de mistério de koinonia, no qual se afirma a diversidade de Pessoas divinas, que, sendo da mesma substância divina, relacionam-se pericoreticamente e se distinguem em propriedade e missão. A unidade na pericórese possibilita que a realização da missão de uma Pessoa seja efetuada em comunhão com as outras duas. O conhecimento dessa realidade divina é efetuado mediante a revelação cristológico-trinitária, em que Cristo, por vontade do Pai e por ação do Espírito, encarna, vive, sofre, morre, ressuscita dos mortos, doa o Espírito para os apóstolos, configurando a Igreja, para que seja sacramento de salvação universal, corpo de Cristo, Povo de Deus, constituído de ministérios e de realidade comunitária. ${ }^{1}$

Essa identificação da Igreja com a Trindade torna-a uma realidade de koinonia e de missão, em sua relação com o mundo, no qual o próprio Deus se revelou plena, completa, perfeita e definitivamente em Jesus Cristo, para que todos os seres humanos experimentem a sua salvação. Deste modo, além da identidade cristológico-pneumático-trinitária, a Igreja possui também a

${ }^{1}$ Cf. CALEBRESE, G. Per un'Ecclesiologia Trinitaria. Il Mistero di Dio e il Mistero della Chiesa per la Salvezza dell'uomo. Bologna: Edizioni Dehoniane, 2000, pp. 25-68. 
identidade escatológica, efetivada na história à medida que se relaciona com o mundo, para realizar a sua missão de anunciar e testemunhar a boa notícia do evangelho. Trata-se de uma missão historicamente permanente, mas que se enraíza em cada época histórica, de modo a objetivar eficácia em suas ações.

Ao considerar a missão da Igreja imbuída de índole escatológica, a ser realizada historicamente nos diversos contextos, há de se realçar a realidade na qual a Igreja se encontra na era contemporânea, denominada de pós-modernidade globalizada. Esta categoria é constituída de diversidade conceitual, tanto filosófica quanto sociologicamente. O âmbito filosófico denota a crise da metafísica, o surgimento da ontologia hermenêutica, o fim das metanarrativas, a emergência da diferença e o surgimento do pensamento rizhômico, a fragmentação da ciência e o pensamento pragmático, a transversalidade e a nomadologia do pensamento. O âmbito sociológico apresenta a diversidade étnica e cultural, a midiatização da cultura, o paradoxo do individualismo e da alteridade, a pós-moralidade, a efemeridade, a vulnerabilidade pluridimensional e a banalização da vida, a ambiguidade entre crise econômica e o consumismo. ${ }^{2}$

Diante deste quadro filosófico e sociológico, a Igreja ainda que tenha identidade originária na Trindade, realiza a sua missão no mundo e assume os dramas, as tristezas, as alegrias e as esperanças da humanidade. ${ }^{3}$ Não obstante a sua ontologia identitária, a Igreja se vê em muitas circunstâncias em profunda crise ou até em situação patológica, ${ }^{4}$ o que pode obscurecer a sua missão. No entanto, é amparando-se em sua identidade trinitária que a Igreja realiza a sua missão, seguindo a própria lógica da revelação trinitária, cujo ápice se encontra no evento Jesus Cristo. Esse evento de encarnação, morte e ressurreição, quando analogamente é apropriado pela Igreja, torna-a também inserida no mundo em sua epocalidade histórica, de modo a se tornar sempre pertinente, relevante e atual em suas ações missionárias. Assim sendo,

\footnotetext{
${ }^{2}$ Cf. GONÇALVES, P. S. L. "A teologia na cultura pós-moderna”. In: SOUZA, N. Teologia em diálogo. Aparecida/SP: Santuário, 2011; OLIVEIRA, M. A. "Pós-modernidade: abordagem filosófica”. In: GONÇALVES, P. S. L. Teologia na Pós-modernidade. Abordagens epistemológica, sistemática e teórico-prática. São Paulo: Paulinas, 2003, pp.21-52; BENEDETTI, L. R. "Pós-modernidade: abordagem filosófica". In: GONÇALVES, P. S. L. Teologia na Pós-modernidade. Abordagens epistemológica, sistemática e teórico-prática. São Paulo: Paulinas, 2003, pp. 53-70.

${ }^{3}$ Cf. CONCÍLIO VATICANO II. "Constituição pastoral Gaudium et Spes", n.1. In: Acta Apostolicae Sedis 58 (1966), pp. 1025-1115.

${ }^{4}$ Cf. KÜNG, H. A Igreja tem salvação? São Paulo: Paulus, 2012.
} 
para atingir o objetivo supramencionado, serão decifrados os conceitos de missão da Igreja e de pós-modernidade, para, em seguida, apontar a respectiva missão no contexto pós-moderno referente ao tema da relação entre cultura e linguagem, a relação entre as confissões religiosas e a busca do bem-estar social.

Nesses anos de pontificado, assumindo a sua condição de pastor da Igreja de Roma, com universalidade na caridade, Francisco tem buscado reformar a cúria romana mediante a perspectiva da humildade, tem legado ao pastoreio presença na qual prioriza as vítimas de injustiças, de tragédias socioclimáticas, as pessoas oprimidas sistemicamente, e realça a cultura do encontro das diferenças que marcam a humanidade. Além disso, seus discursos teológicos, fundamentados na tradição cristã, são incisivamente pastorais e, por conseguinte, com efetiva incidência histórica. Neste sentido, sem se inserir no mundo, a Igreja não realiza a sua missão e, sem realizar a sua missão, a Igreja não efetiva a sua identidade fundada no mistério trinitário, conforme a constituição dogmática Lumen Gentium, do Concílio Vaticano II.

\section{Os conceitos de Missão e de Pós-modernidade}

\subsection{O conceito de missão da Igreja}

A Igreja é concebida como mistério em função de originar-se do mistério trinitário, que é mistério de koinonia das Pessoas divinas e da afirmação da única substancialidade divina. Tem-se, então, a afirmação de um único Deus em termos de substância, constituído de três Pessoas divinas, cuja relação é marcada pela pericorese, que permite a diversidade, em propriedade e missão, e a eterna comunhão na substância. Deste modo, o Pai é o principium principiorum que gera o Filho e que faz proceder o Espírito; o Filho é gerado pelo Pai e faz proceder o Espírito com o Pai; e o Espírito procede de ambos por meio do Filho. Assim sendo, afirma-se que quatro são as relações intradivinas: a geração ativa, que é a relação que possui como terminus a quo o Pai e como terminus ad quem o Filho; a geração passiva, que é aquela que parte do Filho e se dirige ao Pai; a inspiração ativa, que é a relação do Pai e do Filho com o Espírito Santo; e a inspiração passiva, que parte do Espírito Santo e se dirige ao Pai e ao Filho. Cabe ao Pai criar por meio do Filho e na ação do Espírito, ao Filho redimir e salvar por vontade do Pai e por ação do Espírito, e ao Espírito santificar, iluminar e inspirar por vontade do Pai e 
pela mediação do Filho. Tanto a propriedade quanto a missão não se efetivam sem a comunhão das Pessoas divinas, marcadas pela consubstancialidade, comajestade, coigualdade. ${ }^{5}$

A identidade da Igreja se origina no mistério trinitário, revelado plena, completa, perfeita e definitivamente em Jesus Cristo, por desígnio do Pai e por ação do Espírito. Ainda que tenha nexo originário com Cristo e com o Pai, a Igreja surge historicamente com o Espírito, assumindo na sua única substância eclesial, a dupla natureza de divina e humana. Inspirada pelo Espírito, a Igreja assume formas históricas, mas possui um compromisso com o próprio Jesus Cristo: o de anunciar e testemunhar a boa notícia do Evangelho, identificado com o Reino de Deus, cujo significado categorial é a soberania de Deus na história, em aliança com o seu povo, dotado de vitalidade para permanecer na comunhão com Ele. ${ }^{6}$

A koinonia que identifica a Igreja em sua identidade originariamente trinitária é apresentada nas categorias que levam a cabo o mistério da Igreja. A primeira delas é Povo de Deus, cujo fundamento se encontra em Povo de Israel, que fez aliança - berit - com Deus (Gn 12, 1-3; Ex 3, 7-14; Dt 26, 5-10) para ser luz das nações, e na Ekklesia neotestamentária, novo Povo de Deus que evangeliza, batiza, celebra a ceia do Senhor (1Cor 11), forma comunidades constituídas de pessoas dispostas a viver a fé professada em Jesus Cristo. Este Povo agrega também as pessoas de boa vontade que praticam a justiça, ${ }^{7}$ mesmo as que professam outro tipo de fé e que, de algum modo, servem a Deus. Este Povo é um povo messiânico e sacerdotal, que transmite e anuncia a palavra de Deus, celebra os sacramentos e se constitui de ministérios ordenados e leigos, denotativos de caráter servidor, comunitário e missionário. Por isso, é também um povo que é sacramento de salvação universal, sendo sinal e instrumento de Deus neste mundo, em suas diversas épocas históricas. Ao ser comunhão - koinonia, communio -, a Igreja é missão - missio-, pois é na comunhão que a sua missão é realizada, enquanto anúncio e testemunho do evangelho, identificado com o Reino de Deus. ${ }^{8}$

${ }^{5}$ Cf. STAGLiAnÒ, A. Il Mistero del Dio Vivente. Per uma teologia dell'Assoluto trinitário. Bologna: Edizioni Dehoniane, 1996, pp. 525-563.

${ }^{6}$ Cf. CALABRESE, G. Per un'Ecclesiologia Trinitaria, pp. 213-254.

${ }^{7}$ Cf. CONCÍLIO VATICANO II. "Constituição dogmática Lumen Gentium", n. 9. In: Acta Apostolicae Sedis 57 (1965), pp. 5-67.

${ }^{8}$ Cf. KASPER, W. A Igreja Católica. Essência, Realidade, Missão. São Leopoldo: Editora Unisinos, 2011; TAWARD, G. H. A Igreja, Comunidade de Salvação. Uma eclesiologia ecumênica. São Paulo: Paulus, 1998. 
A missio da Igreja é de natureza trinitária, com íntima relação com o Pai, o Filho e o Espírito Santo. Por isso, a Igreja é chamada à intimidade com o Pai, na mediação do Filho e na inspiração iluminadora do Espírito, para consolidarse na história como sacramento de salvação universal. Sua missão de anúncio e de testemunho do Evangelho, por ser universal, não é excludente e se destina ad gentes. Intra gentes e inter gentes, e possui conotação histórica. Isso significa que a Igreja, ao evangelizar, dirige-se para si mesma e para os povos, propondo-se a se relacionar mediante o diálogo e o respeito em perspectiva de alteridade. Para ser eficaz, o movimento evangelizador há de se ater à realidade histórica de seus interlocutores, de modo a tornar-se contemporâneo de cada época histórica. Por isso, o Concílio Vaticano II introduziu o método indutivo na relação da Igreja com o mundo, analisando-o em sua realidade histórica, econômica, cultural, social, política e religiosa. Dessa forma, houve, no Concílio, a colocação da antropologia teológica ao lado da eclesiologia, permeada por uma theologiamundi, em que a revelação de Deus encontra no mundo o seu palco de manifestação. ${ }^{9}$

\subsection{O conceito de Pós-modernidade}

Ao visualizar a contemporaneidade histórica da evangelização, a Igreja, que, no Concílio Vaticano II, preocupou-se em olhar para o mundo contemporâneo a partir da categoria Modernidade, marcadamente antropocêntrica e cientificista, há de se preocupar, nesta época histórica, com a categoria Pós-modernidade, cuja compreensão é complexa e não consensual. De qualquer modo, a compreensão requer que filosoficamente se visualize a sentença nietzscheanina acerca da morte de Deus e o projeto heideggeriano de superação da metafísica, apropriando-se deles tanto na distinção quanto na conjugação entre ambos.

A dita sentença nietzscheniana, realizada no auge da Modernidade, que com Augusto Comte encontrava o seu apogeu científico em perspectiva messiânica, uma vez que a ciência era concebida como instância que resolveria todos os problemas humanos, suscita uma crítica ao discurso metafísico do cristianismo, que permeou a cultura ocidental com sua doutrina e axiologia, e à própria metafísica objetivista presente na ciência moderna. Além disso,

\footnotetext{
${ }^{9}$ Cf. GONÇALVES, P. S. L. "A teologia do Concílio Vaticano II e suas consequências na emergência da Teologia da Libertação". In: GONÇALVES, P. S. L.; BOMBONATTO, V. I. Concílio Vaticano II. Análise e prospectivas. São Paulo: Paulinas, 2004, pp. 69-94.
} 
suscita o sujeito da morte de Deus, o homem moderno, e evoca a figura do super-homem ou além-homem como novo sujeito histórico, em que não há mais o fundamento em que vigora metafisicamente as proposições, mas tudo passa a ser interpretação que propicia a desconstrução do que é sólido. Não há em Nietzsche um ateísmo substancialista, mas hermenêutico de incidência na religião e na formulação da questão de Deus. Neste sentido, a crítica nietzscheniana, que foi interpretada como antirreligiosa e ateísta em seu sentido estrito, propicia pensar uma nova religião ou nova aurora em que Deus dá espaço para o deus ou os deuses, cuja formulação é consoante à própria interpretação conceitual que muda permanentemente. ${ }^{10}$

O projeto de superação da metafísica em Heidegger está relacionado à sua inquietação referente à história do ser desde a década de 1910. Para este filósofo, a metafísica esqueceu-se do ser para envolver-se com o ente, especialmente o ente supremo, tornando-se insuficiente para compreender o ser nesta época histórica. Por isso, no período de 1918 a 1923, elabora uma ontologia fundamental de perspectiva hermenêutica que abarca experiência fática de vida para responder à pergunta de como (Wie) a vida é vivida. No período de 1924 a 1929, produz a sua ontologia hermenêutica existencial, em que o ser se efetiva na temporalidade através do Dasein, cuja existência autêntica se situa na sua transcendência ek-stática de antecipação do futuro e rememoração do passado no presente. Esses dois momentos proporcionaram que Heidegger, ao elaborar as lições sobre os conceitos fundamentais da metafísica, ao pensar a essência do fundamento e da verdade, atingisse a concepção de Ereignis, em que o ser se dá ao homem, encontrando na linguagem a sua morada, de modo que se requer do homem apropriação ao seu acontecimento de manifestação. Não se trata, então, de destruir a metafísica, eliminando-a por completo, até em função de que a metafísica é uma cadeia de montanhas irremovíveis ${ }^{11}$ - é a própria tradição do pensamento ocidental -, mas, sim, de redimensioná-la como ontologia hermenêutica, em que a verdade - aletheia ou veritas - é abertura ao próprio ser que se manifesta como clareira na linguagem do homem. ${ }^{12}$

\footnotetext{
${ }^{10}$ Cf. ALMEIDA, R. M. “'Deus está morto’: A religião na perspectiva de Nietzsche”. In: GONÇALVES, P. SL. (Org.). Um olhar filosófico sobre a religião. Aparecida: Ideias \& Letras, 2012, pp. 51-76; DUQUE, J. M. Para o diálogo com a Pós-modernidade. São Paulo: Paulus, 2016, pp. 17-86.

${ }^{11}$ Cf. VON HERMANN, F. W. Die Metaphysik im Denken Heideggers. Città del Vaticano: Urbaniana, 2004.

${ }^{12}$ Cf. GONÇALVES, P.S.L. "A Teologia como ciência ôntica e sua relação com a Filosofia". Horizonte 35 (2014), pp. 932-956.
} 
As esteiras nietzscheniana e heideggeriana possibilitaram que o pensamento filosófico se desenvolvesse como ontologia hermenêutica, que ultrapassa a dureza positivista da ciência, mediante a estética e a história, e cuja palavra - logos ou verbum - é sempre palavra histórica situada hermeneuticamente. Além disso, desenvolveu-se também o pensamento da diferença nas vertentes da alteridade e do rizhom. Na primeira, destacase Emmanuel Levinas, que afirmava ser o Outro a categoria denotativa da diferença interpelativa, identificada no seu rosto e na sua capacidade de nos chamar à relação face a face. Por isso, a sensibilidade pelo Outro, na sua condição própria de alteridade, possibilita desembocar na ética propiciadora do encontro e, nele, a compaixão e a solidariedade. Na segunda, destaca-se Jacques Derrida, em que a diferença manifesta-se exteriormente de modo pleno na linguagem, encontrando-se com outras diferenças para a realização de um jogo das diferenças. Gilles Deleuze, por sua vez, acentua a diferença utilizando a ideia do rizhom de uma rede formada por pontos distintos interligados uns aos outros, cuja ausência de relação torna o ponto inoperável e insuficiente em sua realidade. O pensamento rizhômico é, pois, um sistema não centralizado, uma multiplicidade descentralizada, não hierárquica, definido única e exclusivamente através da circulação das situações. Na filosofia da diferença emergem as complexificações, a articulação entre conexão e heterogeneidade e, por ser um movimento circular, é um pensamento nômade, cuja unidade está na circulação e na manifestação da diferença. ${ }^{13}$

No âmbito sociológico, a pós-modernidade é irrupção de uma sociedade que ultrapassa moral, as noções de espaço e tempo das sociedades tradicionais, que moderniza tecnologicamente as relações, que une a ciência à tecnologia no âmbito de diversos setores da vida, em especial a saúde e a comunicação, que concentra diversos instrumentos em um único instrumento, ocupando os espaços com novas inteligências técnicas. Além disso, a sociedade pósmoderna valorizou simultaneamente a parte e o todo, de modo a globalizar a economia e a política, sem deixar de manifestar as especificidades em ambas as dimensões. ${ }^{14}$

Com a economia e a política globalizadas, ainda que as singularidades

${ }_{13}$ Cf. OLIVEIRA, M. A. A ontologia em debate no pensamento contemporâneo. São Paulo: Paulus, 2014, pp. 11-42.

${ }^{14}$ Cf. MAFFESOLI, M. O Instante Eterno. O retorno do trágico nas sociedades pós-modernas. São Paulo: Zopuk, 2003; MAFFESOLI, M. O ritmo da vida. Variações sobre o imaginário pósmoderno. Rio de Janeiro/São Paulo: Record, 2007. 
possam ser manifestadas, existem mecanismos que escondem a violência e as vulnerabilidades sociais, étnicas, culturais, religiosas e sexuais causadas pela globalização. Exatamente por haver tais mecanismos, a pobreza das nações, seguramente tendo ultrapassado a regionalização e já consolidada mundialmente, denota um paradoxo: de um lado, há escândalo em função de morte por fome, por doença que poderia ser evitada, por violência de diversas modalidades - inclusive a institucionalizada -, suscitando a pergunta: onde dormirão os pobres? ${ }^{15}$ Acrescente-se ainda a insensibilidade pelo sofrimento, disfarçada pela mídia que o apresenta de forma espetacular, de modo a não mostrar a real causalidade do sofrimento, em termos sociais, econômicos e políticos. De outro lado, constata-se a existência de pessoas e instituições comprometidas e compadecidas com os pobres, sensíveis pelo sofrimento, preocupadas em primar pela vida. Em outras palavras, há um enorme estado de crise e de tensão pela superação da crise, de vida líquida e de movimentação, para que a vida seja afirmada em sua profunda dignidade humana e cósmica. ${ }^{16}$

Nesta sociedade, surgem diversos modelos de espiritualidade religiosa e arreligiosa para superar o mundo veloz e agitado, para superar o sofrimento pessoal e coletivo, para encontrar formas que viabilizem a edificação da civilização do amor, da cultura mundial da solidariedade, da ecologia integral. Em função do paradoxo que é próprio da pós-modernidade, há movimentos de espiritualidade que visam a felicidade em âmbito individual, priorizando ora a dimensão psíquica, ora a dimensão corpórea da pessoa, mas sem incidir no ethos comunitário, que é teologicamente intrínseco ao conceito de pessoa.

É neste quadro brevemente esboçado que a permanente missão da Igrejaevangelizar - ou a presença da Igreja, como missio com identidade koinônica, há de se realizar na sua relação com o mundo contemporâneo.

\section{A missão da Igreja: evangelizar em cada época histórica}

\subsection{Elementos fundamentais}

A missão da Igreja é anunciar a boa notícia do evangelho, que é o próprio Jesus, Filho de Deus, que doou o Espírito para inspirar e iluminar a Igreja a ser Povo de Deus, sacramento de salvação universal e corpo de Cristo. A realização

\footnotetext{
${ }^{15}$ Cf. GUTIÉRREZ, G. Onde dormirão os pobres. São Paulo: Paulus, 1996.

${ }^{16}$ Cf. BAUMAN, Z. O mal-estar da Pós-modernidade. Rio de Janeiro: Zahar, 1998; BAUMAN, Z. Modernidade e Ambivalência. Rio de Janeiro: Zahar, 1999.
} 
dessa missão se efetiva na história, exigindo que se situe contemporaneamente em cada época histórica. Neste sentido, o fenômeno pós-modernidade, que é um fenômeno epocal, é o locus de inserção da Igreja na realização de sua missão. É diante deste fenômeno que a Igreja anuncia o evangelho, que é a palavra de Deus, o próprio Jesus Cristo, que se encarnou e deixou à Igreja tal missão, cujo campo se apresenta na existência pessoal de cada ser humano, na sociedade e na relação com as outras igrejas cristãs e religiões. Disso resulta que a Igreja, ao estar em missão, é missão e, por consequência é Igreja em saída, ${ }^{17}$ que se abre para o mundo, com a finalidade de anunciar e testemunhar o evangelho. Por isso, a categoria primeirear ${ }^{18}$ remete à experiência de Deus como primeiro sujeito histórico da evangelização, impulsionando a Igreja ao envolvimento com a existência humana em todas as suas dimensões e com a casa comum. Trata-se de um envolvimento cotidiano e profundo, de modo que a Igreja participe ativamente da vida das pessoas, contribua com a construção de sociedades justas e fraternas, com uma cultura mundial da paz e da solidariedade, com uma civilização do amor e com uma ecologia integral. A pastoral da Igreja compreendida em chave missionária propicia que a evangelização seja nova evangelização em ardor, em métodos, em presença da Igreja no mundo, o que lhe exige conversão e discipulado missionário, ${ }^{19}$ como honra a própria apostolicidade da Igreja, compreendida como nota eclesial tradicional. Isso significa que a Igreja, em missão e como missão, irrompe um processo de reestruturação eclesial interna, em que os interesses individuais e a mundanização da estrutura são superados, para dar lugar a espaços eclesiais de convivência assinalada pela alteridade que implica respeito, reciprocidade, corresponsabilidade e todo movimento denotativo de koinonia, oriunda da própria koinonia trinitária. ${ }^{20}$

O primeireamento é um envolvimento em que a Igreja tem consciência de sua origem divina e também de sua dimensão humana, indicativa de que as pessoas missionárias possuem limites e que as estruturas são também limitadas.

${ }^{17}$ Cf. FRANCISCO, PP. "Exortação Apostólica Evangelii Gaudium”, n. 20. In: Acta Apostolicae Sedis 105 (2013), pp. 1020-1138.

${ }^{18}$ Cf. FRANCISCO, PP. "Exortação Apostólica Evangelii Gaudium”, n. 24. In: Acta Apostolicae Sedis 105 (2013), pp. 1020-1138.

${ }^{19} \mathrm{Cf}$. CONFERÊNCIA GERAL DO EPISCOPADO LATINO-AMERICANO. Documento de Aparecida. Texto conclusivo da V Conferência Geral do Episcopado Latino-Americano e do Caribe. São Paulo: Paulus / Paulinas, 2007, n. 146-147.

${ }^{20}$ Cf. MIRANDA, M. F. A reforma de Francisco. Fundamentos teológicos. São Paulo: Paulinas, 2017. 
Disso resulta que o espírito de abertura a outrem e às novidades históricas há de se apresentar permanentemente à Igreja, como expressão de abertura ao próprio mistério de Deus que se revela na história. Esse envolvimento requer que a Igreja tenha sempre a consciência de que a evangelização se efetiva pelo anúncio e testemunho da palavra de Deus. Por isso, insiste-se em que os meios de evangelização devam ser utilizados com ardor e espiritualidade missionários, requerendo constante e profunda preparação, comprometimento e empenho dos agentes de evangelização, membros da Igreja, povo de Deus, corpo de Cristo - historicamente ministerial e atuante - e sacramento - sinal - de salvação universal. ${ }^{21}$

Em sua missão, a Igreja se atém à realidade histórica dos povos, compreendidos singularmente e na relação de uns com os outros, em sua cultura, economia, política, forma social de organização e religiosidade. Atémse também às diversas formas religiosas cristãs, especialmente a piedade popular, e as possibilidades de acolhimento no processo de evangelização. Importa o justo desenvolvimento da homilia e de outros meios de pregação para que o evangelho seja acolhido e vivido pelas mais diversas pessoas. ${ }^{22}$

O anúncio do evangelho é emissão de palavras para brilhar a palavra de Deus, transmitida pela Igreja, a todos os povos. A palavra no cristianismo era Deus, estava com Deus e habitou entre os seres humanos (Jo 1,1). A habitação da palavra ou a encarnação do Verbo é a própria presença de Deus na história humana, em forma de linguagem, concebida filosoficamente como a casa do ser ou a morada do encontro entre o ser e o homem, cujas formas linguísticas se diversificam em conformidade com as formas de comunicação. Assim sendo, a palavra pode ser pronunciada mediante a verbalização, os símbolos e as ações, ou testemunhos do agir propriamente cristão. Em todas as instâncias, a palavra é linguagem e denota. Inspira e promove a vida, porque emerge de um processo comunicativo entre as pessoas, cujo desenvolvimento há de levar ao consenso nas decisões e resultados comunicacionais. Por isso, o diálogo é o canal e a própria luz do processo comunicativo, em que a pronúncia é acompanhada da escuta, cujos ouvidos estão atentos em função de que estão em conexão com uma mente capaz de escutar, para, dessa maneira, originar a fala que se direciona para o que foi escutado. O diálogo é uma combinação dos termos dien e logos, que significa a luz sapiencial ou a sabedoria iluminadora.

\footnotetext{
${ }^{21}$ Cf. FRANCISCO, PP. "Exortação Apostólica Evangelii Gaudium”, n. 19-49.

${ }^{22}$ Cf. FRANCISCO, PP. “Exortação Apostólica Evangelii Gaudium”, n. 110-159.
} 
Neste sentido, a palavra pronunciada é provocadora e interpeladora para quem a escuta, de modo que quem a escuta, quando fala, responde à provocação ou interpelação, propiciando a réplica e, por conseguinte, a tréplica, de tal maneira que o resultado seja o consenso e não imposição de um sobre o outro. Disso resulta a relevância da homilia e da catequese na evangelização, as quais devem ser preparadas com a intensidade da fé, para que seja praticada a caridade e suscitada a esperança no cristianismo.

No âmbito dos símbolos também prevalece o diálogo na evangelização à medida que o símbolo de quem é evangelizado é respeitado em sua condição de diferente e próprio. O símbolo há de ser pensado em função de que possui vida, contextualizada na produção cultural de cada grupo ou povo. É imbuído de potencial comunicador e tem o que falar em termos de tradição e vitalidade dos ritos religiosos e sociais. Por isso, quem evangeliza há de dizer ao símbolo e escutá-lo, de tal modo que nova vitalidade esteja presente no símbolo. A ação ou o testemunho é outra instância de evangelização, em função de que o próprio agir é a palavra em ação transformadora de uma determinada realidade. Quando se age, a palavra se torna realidade histórica, resultado de um processo de transformação causado pela palavra-ação ou ação, que é palavra cortante, viva e eficaz. Na ação, a palavra é o próprio silêncio da verbalização e do símbolo, que dão lugar para que o silêncio seja a palavra da ação e para que a ação seja palavra que age transformadoramente na realidade histórica.

A efetividade da palavra está relacionada à cultura dos destinatários do evangelho. Evidentemente que o evangelho se assenta em uma substância cultural, que, historicamente, é produto de relações culturais, mas o seu devir é ser boa notícia para os povos aos quais é anunciado e testemunhado. Por isso, o conceito de inculturação do evangelho é de fundamental importância para a eficácia da missão evangelizadora da Igreja. Trata-se de um conceito teológico que se articula com os conceitos antropológicos de cultura, enculturação e aculturação. Por cultura, compreende-se a totalidade dos produtos humanos realizados por um povo e assimilados por cada pessoa que o constitui. Os costumes, o habitat, a infraestrutura básica, a ética e a religião constituem a cultura de um povo. A cultura articula as respectivas subsistências presentes na materialidade, na organização social e na interpretação de um povo com os seus registros radicados no imaginário, na simbologia e na realidade cotidiana. O conceito de enculturação refere-se ao fato de que as pessoas aprendem a sua própria cultura antes de se aproximarem de outra cultura. Cria-se uma raiz forte na identidade cultural de cada pessoa. Por aculturação, compreende-se 
o processo de aproximação entre os representantes das diferentes culturas, para que se efetive um processo de adaptação mútua. Assentada nesses três conceitos, a inculturação é a boa notícia do evangelho, anunciada e recepcionada na matriz da própria cultura autóctone, de modo a produzir a boa convivência entre o evangelizador e as pessoas da cultura evangelizada, transformação da realidade social e histórica, a relação respeitosamente corresponsável no que se refere às identidades religiosas. ${ }^{23}$

Ao considerar que a missão da Igreja é evangelizar de modo situado em cada época histórica, a linguagem da palavra evangelizadora há, então, de ser marcada pela inculturação, que supõe um processo hermenêutico que visualize de modo efetivo a realidade a ser evangelizada. Logo, a palavra verbal, simbólica e ética - forma de ação - não pode ter a marca de uma metafísica objetivista, que nutre o dogmatismo, o moralismo, o legalismo, nem de um verticalismo organizacional, que impede a efetivação das estruturas de comunhão e o espírito do diálogo, que é essencial na missão eclesial. Ao ser revestida da hermenêutica, a linguagem da missão evangelizadora é portadora da verdade, mantendo-se em suas expressões um espírito de abertura e diálogo, de forma que esteja sempre a serviço da verdade revelada. A hermenêutica, em vertente ontológica, não se opõe à metafísica, que constitui a própria tradição da teologia cristã, mas a reconfigura para colocá-la em um processo de que a tradição da própria revelação cristã se atualiza em cada época histórica. ${ }^{24}$

\subsection{Ecumenismo e diálogo inter-religioso}

A relação da Igreja com as outras religiões se desenvolve no âmbito da unidade inter-religiosa e dos cristãos. A unidade dos cristãos é denominada de ecumenismo e sua emergência possui tanto caráter histórico quanto teológico. Historicamente, as divisões do cristianismo estão situadas, tais como o cisma entre ocidente e oriente no século XI e a reforma protestante do século XVI. Posições muitas vezes sectárias e contrárias à promoção da unidade foram construídas, ainda que o debate em torno de questões teológicas de grande

${ }^{23}$ Cf. GONÇALVES, P. S. L. "Cristianismo hoje e amanhã: fé e cultura". In: BINGEMER, M. C.; ANDRADE, P. F. C. (Org.). O mistério e a história. Ensaios de teologia em homenagem ao Pe. Félix Pastor por ocasião dos seus 70 anos. São Paulo: Loyola, 2003, pp. 172-205; SUESS, P. "Inculturación". In: ELLACURÍA, I.; SOBRIÑO, J. Mysterium Liberationis. Conceptos fundamentales de la teologia de la liberación. Madrid: Trotta, 1990, pp. 377-422.

${ }^{24}$ Cf. GEFFRÉ, C. Fazer Teologia hoje. São Paulo: Paulus, 1989; GEFFRÉ, C. Crer e interpretar. Petrópolis: Vozes, 2004. 
envergadura epistemológica e dogmática surgiram como instâncias para que fossem criados espaços de debate. ${ }^{25} \mathrm{~A}$ era contemporânea está marcada por esforços de efetivação do ecumenismo, desde a criação do Conselho mundial das Igrejas, a constituição de comissões mistas constituídas de pessoas da Igreja católica e outras instituições religiosas cristãs que se debruçaram sobre diversos assuntos de ordem ecumênica, até o Concílio Vaticano II, em que a Igreja católica abraçou definitivamente a causa do ecumenismo, firmando-se em seus princípios católicos e propiciando diversas iniciativas denotativas da unidade dos cristãos, seja na dimensão prática seja na dimensão teórica.

A dimensão prática do ecumenismo refere-se às realizações de orações em comum, de ações sociais conjuntas, de debates teológicos e pastorais, de visitas mútuas entre igrejas e entre pastores. ${ }^{26} \mathrm{~A}$ dimensão teórica está marcada por uma teologia histórica, em que se analisam as razões da separação dos cristãos, especialmente os cismas supracitados, as possibilidades e os eventos ocorridos de promoção da unidade dos cristãos, e a teologia que sustenta propriamente o movimento ecumênico ${ }^{27}$ Esta dimensão também carrega a

${ }^{25}$ Cf. O'COLLINS, G. Fundamental Theology. New York/Mahwah: Paulist Press, 1981, pp. 192-208. Um exemplo disso é o tema das fontes da revelação, em que o princípio luterano solo scriptura oriundo do próprio Lutero se contrapunha à concepção acerca das duas fontes da revelação, vigente na Igreja e consolidada no concílio de Trento. O debate se estendeu e foi desenvolvido no Concílio Vaticano II, especialmente na constituição dogmática Dei Verbum, em que se afirmou a primazia da palavra de Deus, presente na Escritura e transmitida ao longo da tradição eclesial.

${ }^{26}$ Duas perspectivas servem de exemplos para apontar o caminho ecumênico atual. A primeira é CEDRA. Caminhos para a unidade cristã. Pastoral de Ecumenismo. São Paulo: Paulinas, 1987. Trata-se de uma obra produzida pela Comissão para o Ecumenismo e Diálogo Religioso da Arquidiocese de São Paulo, em que se narra teológico-pastoralmente as experiências ecumênicas dessa arquidiocese. São caminhos reais no âmbito dos sacramentos, das orações, dos diálogos teológicos, das questões pastorais e catequéticas e de encontros específicos em que as igrejas diversas se unem para celebrar, encontrar-se, conviver umas com as outras. $\mathrm{O}$ segundo exemplo se situa em TIEL, G. Ecumenismo na perspectiva do reino de Deus. Uma análise do movimento ecumênico de base. São Leopoldo: Sinodal, 1998. Trata-se de uma pesquisa densa, em um campo pouco apresentado pelas instituições eclesiásticas: o ecumenismo de base, que é aquela atividade de unidade das pessoas religiosas, especialmente as cristãs, que se configuram como um ecumenismo prático, marcado pela comunhão, solidariedade, compaixão e fraternidade. Emergem conceitos teológicos importantes, amparados pelas ciências humanas, tais como sincretismo e inculturação, além de apontar a categoria reino de Deus, como elemento central na formulação de uma teologia pastoral ecumênica.

${ }^{27}$ Cf. GIRAULT, R. Construire L'Eglise Une. Nouveaux chemins oecuméniques. Paris: Desclée de Brouwer, 1990; HORTAL, J. E haverá um só rebanho. História, doutrina e prática católica do Ecumenismo. São Paulo: Loyola, 1989; NEUNER, P. Ökumenische Theologie.Die Suche nach der Einheit der christlichen Kirchen. Darmstadt: Wissenchaftliche Buchgesellschaft, 1997. 
marca de uma teologia sistemática ecumênica, em que se pensa a pneumatologia ecumenicamente, especialmente de diálogo entre a Igreja católica e as Igrejas orientais, chamadas também de igrejas irmãs, formulando uma pneumatologia histórica, trinitária e cristológica, e que busca encontrar na doutrina do Filioque um caminho efetivo de diálogo e unidade entre as teologias e igrejas cristãs. Pensa-se também em uma cristologia de cunho soteriológico, que abarque não apenas a confessionalidade cristã, mas também a proximidade e o diálogo com outras religiões. Disso resulta uma compreensão de Jesus como símbolo de Deus ${ }^{28}$ ou de uma cristologia ao encontro das religiões, ${ }^{29}$ ou ainda de uma cristologia que afirma o único Cristo $^{30}$ tanto em termos ecumênicos quanto inter-religiosos e cósmico.Ainda se pode pensar em uma eclesiologia que reinterpreta o ditado berlaminiano Extra ecclesia nulla salus à luz da koinonia, tão evidente e prezada no Concílio Vaticano II, propiciando a formulação ecumênica das notas da Igreja, em que a inserção da Igreja no mistério trinitário possibilita pensar complexamente a unidade, a santidade, a catolicidade e a apostolicidade da Igreja. ${ }^{31}$

O caráter inter-religioso da evangelização se destaca já na teologia das religiões, em que se constata sociológica e teologicamente o pluralismo religioso, considerando o caráter mundial do cristianismo e, propriamente, a universalidade soteriológica, que constitui a teologia cristã. Tem-se uma teologia das religiões sistematizada no que se refere à sua história, epistemologia e elementos fundamentais, ${ }^{32}$ possibilitando uma teologia cristã de cunho reinocêntrico, ainda que suscite uma cristologia teocêntrica e o pneumatocentrismo para que o cristianismo dialogue com as outras religiões monoteístas e com as religiões brâmanes respectivamente. ${ }^{33}$ Desenvolve-se também uma teologia hermenêutica inter-religiosa, que retoma os critérios

${ }^{28}$ HAIGHT, R. Jesus, símbolo de Deus. São Paulo: Paulinas, 2003.

${ }^{29}$ DUPUIS, J. Gesú Cristo incontro alle religioni. Assisi: Cittadella Editrice, 1989.

${ }^{30}$ DUQUOC, C. O único Cristo. A sinfonia adiada. São Paulo: Paulinas, 2008.

${ }^{31}$ Cf. SUllivAN. F. A. The Church We Believe in. One, Holy, Catholic and Apostolic. New York/Mahwah:Paulist Express, 1988; SULLIVAN. F. Salvation outside the Church? Tracing the History of the Catholic Response. London: Geoffrey Chapman, 1992; GONÇALVES, P. S. L. "O sonho da unidade dos cristãos. Eclesiologia ecumênica elaborada a partir dos "princípios católicos" e das comissões mistas". In: BIZON, J.; DRUBI, R. (Org.). A unidade na diversidade. Coletânea de artigos em comemoração aos 40 anos do decreto Unitatis Redintegratio sobre o ecumenismo. São Paulo: Loyola, 2004, pp. 199-241.

${ }^{32}$ Cf. KNITTTER, P. F. Introdução às Teologias das Religiões. São Paulo: Paulinas, 2008.

${ }^{33}$ Cf. DUPUIS, J. Verso um Teologia Cristiana del pluralismo religioso. Brescia: Queriniana, 1997. 
fundamentais da epistemologia teológica para pensar as religiões, realça a identidade do cristianismo e a necessidade de relacionar-se com as outras religiões, considerando a alteridade e a respectiva identidade religiosa, e ainda suscita o debate relativo à sociedade laica, na qual torna possível o convívio entre as pessoas de diversas religiões e das pessoas religiosas com as pessoas seculares. ${ }^{34}$

O ecumenismo e o diálogo interreligioso são não só realidades atuais, mas também urgentes em seu aprofundamento e efetividade de seus desdobramentos, sobretudo para que se construam a paz mundial e a civilização do amor. Disso resulta que a missão da Igreja não pode abdicar desses componentes e, por conseguinte, a Igreja necessita continuar a levar a cabo tanto a perspectiva ecumênica quanto a relação comunitária com as outras religiões. No diálogo com as outras igrejas cristãs e com as outras religiões, o anúncio do evangelho deverá ser feito com respeito, considerando a alteridade, a respectiva identidade religiosa e a possibilidade de levantar elementos de identificação inter-religiosa.

O processo evangelizador no âmbito do ecumenismo e da relação do cristianismo com outras religiões não se fará sem o diálogo. Aliás, o diálogo é um elemento espiritual da evangelização, por ser o evangelho de caráter universal. Então, a Igreja que evangeliza há também de anunciar o evangelho aos demais cristãos e às pessoas de outras religiões, mediante o diálogo, considerado sempre um processo comunicativo, cujo resultado é o consenso nas expressões e a comunhão de vida. A unidade emergente do diálogo ecumênico e inter-religioso é contribuição para a unidade de todo o gênero humano, para o estabelecimento da paz e da boa convivência entre os povos.

À Luz do diálogo, a Igreja haverá de discernir as instâncias de efetividade do diálogo: a dos outros cristãos, a dos pentecostais, a das religiões monoteístas, a das religiões brâmanes, a das religiões indígenas, as religiões africanas e outras religiões. O diálogo que objetiva a unidade se desenvolverá mediante a concentração na liberdade religiosa como dignidade humana, nos elementos que propiciam a comunhão, e na hierarquia das verdades,${ }^{35}$ que constituem

\footnotetext{
${ }^{34}$ Cf. GEFFRÉ, C. De Babel a Pentecostes. Ensaios de teologia inter-religiosa. São Paulo: Paulus, 2013; GONÇALVES, P. S. L.; FAVRETTO, A. B. “A liberdade religiosa na Declaração Dignitatis Humanae: elementos para uma nova teologia das religiões e para uma inserção da religião no espaço público". Atualidade Teológica 54 (2016), pp. 664-685.

${ }^{35}$ Cf. CONCÍLIO VATICANO II. "Decreto Unitatis Redintegratio", n. 4. In: Acta Apostolicae Sedis 57 (1965), pp. 90-107.
} 
em critério fundamental para o ecumenismo e a comunhão inter-religiosa. $\mathrm{O}$ diálogo ecumênico e inter-religioso é um meio de propiciar que a unidade das instâncias religiosas, marcada pela alteridade entre as religiões, seja um dos grandes caminhos para a paz no mundo, pois "não haverá paz entre as nações, senão existir paz entre as religiões. Não haverá paz entre as religiões, se não existir diálogo entre as religiões". ${ }^{36}$

\subsection{A dimensão social da evangelização}

A missão evangelizadora da Igreja possui também uma dimensão social, na qual se pensa o convívio dos seres humanos em sociedade. $\mathrm{O}$ conteúdo da evangelização é social, porque o seu centro é a caridade, considerada como o amor em movimento, que já estava presente no próprio evento de revelação cristã, em que a redenção assume um sentido social e a salvação se identifica com a libertação integral do ser humano. ${ }^{37} \mathrm{~A}$ considerar a universalidade da redenção e da salvação, o anúncio do evangelho está relacionado à prática da caridade, cuja forma social denota a imanência da própria transcendência que caracteriza o ser humano como pessoa, em sua condição de ser comunitário, capaz de socializarse com outrem e ecológico na relação com o universo. Desse empenho evangelizador que ultrapassa fronteiras e incide socialmente, apresenta-se a esperança cristã, que articula história e escatologia. ${ }^{38}$

O rico patrimônio do ensino social da Igreja $^{39}$ apresenta a profundidade da palavra de Deus nas questões sociais, evidenciando que teologicamente os seres humanos são irmãos, filhos no Filho Jesus. Por isso, há de se idealizar uma sociedade justa, fraterna, constituída de paz nas relações interpessoais e nas relações sociais, marcada por uma cultura da solidariedade e marcada pela integralidade ecológica, na qual o homem e a natureza planetária e cósmica vivem a koinonia. À medida que a evangelização se articula com as questões sociais. Inclusive suscitando a contribuição das ciências para a elevação do humanum na sociedade, do

\footnotetext{
${ }^{36}$ Cf. KÜNG, H. As religiões do mundo. Em busca dos pontos comuns. Campinas: Vertus, 2004, p. 17.

${ }^{37}$ Cf. CONGREGAÇÃO PARA A DOUTRINA DA FÉ. "Instrução Libertatis Conscientia", n. 63. In: Acta Apostolicae Sedis 79 (1987), pp. 554-599.

${ }^{38}$ Cf. FRANCISCO, PP. “Exortação Apostólica Evangelii Gaudium”, n. 176-181.

${ }^{39}$ Cf. ANTONCICH, R.; SANS, J. M. M. Ensino Social da Igreja. Petrópolis: Vozes, 1987.
} 
planeta Terra no universo, e para a conscientização acerca da ecologia da vida, tem-se, então, a promoção integral da vida, de modo particular da vida humana em todas as suas dimensões. ${ }^{40}$

Em uma mensagem de rádio emitida no dia 11/09/1962 - quando faltava um mês antes de iniciar o Concílio Vaticano II -, João XXIII evocava a Igreja dos pobres nos países subdesenvolvidos, cuja terminologia entusiasmou aos padres conciliares, embora não tenha havido elaboração tão profunda acerca do significado desse termo, mesmo que a questão dos pobres não tenha passado sem atenção pelos participantes do Concílio. Entretanto, foi com Paulo VI que o tema dos pobres obteve maior repercussão em articulação com o que se denominou desenvolvimento integral do ser humano, evidenciando que a pobreza deveria ser sempre tema da Igreja. ${ }^{41}$ No entanto, é na II Conferência Geral do Episcopado Latino-americano que a questão dos pobres se acirra e possui profundidade, quando se caracteriza a pobreza como carência, estado de espírito evangélico e compromisso com os pobres. Efetiva-se a passagem da pobreza como tema para perspectiva, de modo que a opção pelos pobres caracterizou-se como cristocêntrica ${ }^{42}$ e teocêntrica, por se tratar de uma opção que Deus faz pelos pobres para se autocomunicar com todos os seres humanos, em Cristo. O cristocentrismo e o teocentrismo possibilitam pensar a mundialização da opção pelos pobres, ${ }^{43}$ de modo que ela não se situa apenas no continente latino-americano e caribenho ou nos denominados países subdesenvolvidos, mas em todas as realidades de pobreza que carrega as marcas da opressão, da injustiça, da violência, da morte prematura. ${ }^{44}$

Resulta, portanto, uma sensibilidade eclesial para se situar no locus dos pobres, enquanto locus privilegiado da revelação cristã, pela qual emerge uma ética do cuidado social e espiritual para com os pobres, propiciando a profecia que denuncia todo tipo de injustiça e negligência social que assola

\footnotetext{
${ }^{40}$ Cf. FRANCISCO, PP. “Exortação Apostólica Evangelii Gaudium”, n. 182-185.

${ }^{41}$ Cf. PAULO VI, PP. “Carta encíclica Populorum Progressio”. In: Acta Apostolicae Sedis 59 (1967), pp. 257-299.

${ }^{42}$ Cf. BENTO XVI, PP. "Discurso Inaugural dosa trabalhos da V Conferência Geral do Episcopado da América Latina e do Caribe. In: Conferência Geral do Episcopado Latino-americano e Caribenho". In: CELAM. Conferência Geral do Episcopado Latino-americano e Caribenho. São Paulo: Paulus / Paulinas, 2007, pp. 268-269.

${ }^{43}$ Cf. JOÃO PAULO II, PP. "Carta encíclica Sollicitudo Rei Socialis”, n. 40-44. In: Acta Apostolicae Sedis 80 (1988), pp. 513-586.

${ }^{44}$ Cf. GUTIÉRREZ, G. La verdad los hara libres. Salamanca: Sal Terrae, 1984.
} 
a dignidade humana. Essa ética possui como imperativo "liberta o pobre", busca caminhos de libertação e de transformação da realidade marcada pelo binômio opressão-libertação. ${ }^{45}$ Por isso, urge uma economia que não seja de mercado, embora possa haver mercado à medida que contribui para 0 estabelecimento da equidade econômica e social. Aliás, a equidade recorda o bem comum e a dignidade da pessoa, elementos que deveriam nortear a política econômica mundial e possibilitar o desenvolvimento integral e uma globalização humanizadora e efetivamente justa. Em sua permanente opção pelos pobres, em função do cristocentrismo e do teocentrismo, a Igreja há de olhar para a pobreza em cada época histórica e descobrir os novos pobres os moradores de rua, os toxicodependentes, os refugiados, os indígenas, os negros, as mulheres, os idosos, as crianças, as vítimas das diversas formas de tráfico, os nascituros - especialmente os mais frágeis dentre os frágeis. Essa sensibilidade se fundamenta na própria misericórdia, que é o nome de Deus, ${ }^{46}$ o princípio que estrutura a Igreja e a teologia, porque coloca o amor em movimento nas atitudes dos cristãos e de todas as pessoas de boa vontade que praticam a justiça. O horizonte ecológico também se apresenta na opção pelos pobres, sobretudo quando se ouve o grito da terra e, ao escutá-la, contemplase tanto esse planeta quanto o universo todo, como espaços da revelação do Cristo cósmico.

Ao considerar os pobres, em sua tríplice dimensão, como locus de revelação, a Igreja afirma o seu compromisso com o bem comum e a paz social. Quando se pensa a paz à luz do evangelho, não se tem apenas a contraposição e a cessação da guerra, mas a ordem desejada por Deus, "que traz consigo uma justiça mais perfeita entre os homens". ${ }^{47}$ Trata-se da paz, que emerge do desenvolvimento integral e do respeito, e da promoção da dignidade do ser humano, cujo ápice se encontra na efetividade do humanum na singularidade de cada pessoa e na constituição do povo, em sua condição de sujeito histórico, integrado na sociedade que constrói sob os fundamentos da justiça, da alteridade, da fraternidade e da paz. Neste sentido, o povo se afirma em sua nação, com sua configuração estatal e respectivo ordenamento jurídico e busca conviver com outros povos, sendo respeitado e sabendo

\footnotetext{
${ }^{45}$ Cf. DUSSEL, E. D. Caminhos de Libertação latino-americana (IV). São Paulo: Paulinas, 1984.

${ }^{46}$ Cf. FRANCISCO, PP.; TORNIELLI, A. O nome de Deus é misericórdia. São Paulo: Planeta, 2016.

${ }^{47}$ Cf. PAULO VI, PP. “Carta encíclica Populorum Progressio”, n. 76.
} 
respeitar a outrem, de modo que haja colaboração mútua e se promova uma cultura do encontro. ${ }^{48}$

Nesta cultura, o tempo é superior ao espaço, a realidade é superior à ideia e o todo é superior à parte, a fim de que se dê tempo ao conhecimento mútuo e responsável entre as pessoas, para ordenar os espaços sociais, de modo a torná-los benéficos a todos os seres humanos que os ocupam, para apreender o conflito, visando à sua superação, mediante a realização de ações pacíficas e do desenvolvimento da comunhão nas diferenças culturais, religiosas e pessoais. ${ }^{49}$ Resulta, então, que a unidade é superior ao conflito, ${ }^{50}$ a solidariedade tornase um estilo de construção da história e os povos no planeta e as pessoas no convívio social propiciam a elevação da unidade, como superior e superação do conflito. Não se trata de uma mistura das diferenças, isenta de fundamento ou uma diversidade isenta de conflitos e problemas, mas de uma unidade que denota as diferenças em comunhão, fundadas sempre na paz do evangelho, que é o próprio Cristo, a paz da humanidade por excelência. Nesta perspectiva, a paz atinge a profundidade da existência humana, propiciando a pessoa solidária - categoria tão rica na doutrina social da Igreja - e o dinamismo da sociedade, que se estabelece em um movimento de unidade na diversidade e diversidade na unidade.

Afidelidade à realidade, que nada mais é do que aquilo que é, mantendose superior à ideia, que é aquilo que ainda há de ser elaborado, propicia que nenhuma ideia seja elaborada sem consonância com a realidade, sem fidelidade histórica ao que foi humanamente construído e precisa ainda de transformação para atingir o que é efetivamente do evangelho. A superioridade do todo em relação à parte mostra a universalidade concreta da própria realidade. A parte não pode nem deve se sobrepor ao todo, nem o todo deve conter uma universalidade que elimina a parte. O universalismo não é abstrato e globalizante de modo a uniformizar as realidade singulares e próprias; nem o localismo ou a parte é um museu folclórico de eremitas localistas, miméticos e isolados das relações que alargam horizontes. $\mathrm{O}$ todo é manifestação do encontro das partes, cujo olhar, de cada uma, se alarga e se estende para o reconhecimento mútuo, realizado em um processo de doação recíproca entre as partes. Por isso,

\footnotetext{
${ }^{48}$ Cf. FRANCISCO, PP. “Exortação Apostólica Evangelii Gaudium”, n. 218.

${ }^{49}$ Cf. FRANCISCO, PP. "Exortação Apostólica Evangelii Gaudium”, n. 222-228.

${ }^{50}$ FRANCISCO, PP. “Exortação Apostólica Evangelii Gaudium”, n. 228.
} 
o poliedro é apresentado como modelo de sociedade, pois reflete "a confluência de todas as partes que nele mantêm a sua originalidade". ${ }^{51}$ Neste sentido, a sociedade se torna inclusiva, contendo todas as partes que as constituem, de modo que se extinga o abismo entre ricos e pobres e se edifique uma sociedade justa, solidária e fraterna. ${ }^{52}$

Disso resulta a relevância do diálogo social que a Igreja, ao proclamar o evangelho da paz, há de realizá-lo com os Estados, em suas instâncias nacionais e internacionais, e com a sociedade em suas diversas configurações. Trata-se de um diálogo em que a Igreja terá a tarefa de buscar salvaguardar que tanto os Estados quanto a sociedade tenham instâncias de diálogo e de busca de consenso com o povo, visando ao fim de posturas e ordenamentos autoritários. Disso resulta a necessidade de trazer à tona os princípios da subsidiariedade e da solidariedade e de contribuir para que as devidas instâncias encontrem soluções específicas para os problemas sociais que afligem os povos e os seres humanos compreendidos em sua singularidade pessoal. Ademais, ao buscar o diálogo, a Igreja há também de incentivar e estimular que as instâncias sociais promovam o diálogo entre si e que extingam posturas sectárias e dogmatistas.

A Igreja há também de promover o diálogo da fé com a ciência, como forma de favorecimento da instauração da paz. Admite-se que as vias da revelação são a da fé e a da razão, e que há a possibilidade de articulação entre ambas, com preponderância da lumen fidei. Neste diálogo não comporta nem o racionalismo e nem o fideísmo, por serem posturas extremistas e com o espírito de contraposição ao diálogo. Trata-se de um diálogo que tem se consolidado à medida que ambas as instâncias se abrem à compreensão mútua e se dispõem a servir a verdade. A fé impulsionará a ciência à construção de raciocínios que contribuam para a elevação da dignidade do homem, o cuidado do planeta e a promoção da vida em seu todo. Por sua vez, a ciência contribuirá para que a fé encontre na razão científica um meio de servir à própria verdade, da qual essa mesma fé é eminente servidora. Na própria teologia, compreendida como scientia fidei, utiliza-se a mediação científica, além daquela da filosofia, para tornar crível a revelação divina.

\footnotetext{
${ }^{51}$ FRANCISCO, PP. “Exortação Apostólica Evangelii Gaudium”, n. 236.

${ }^{52}$ Cf. JOÃO PAULO II, PP. "Discurso inaugural da III Conferência Geral do Episcopado Latino -americano em Puebla”. In: CONFERÊNCIA GERAL DO EPISCOPADO LATINO-AMERICANO. III Conferência Geral do Episcopado Latino-americano. A evangelização no presente e no futuro da América Latina. São Paulo: Loyola, 1982, pp. 24-29.
} 
Enfim, o diálogo social da Igreja com os Estados e a sociedade há de ser permanente e constitutivo da própria missão da Igreja, visando a edificar o evangelho nas formas de justiça social, de cultura de solidariedade e de encontro fraterno, de proximidade entre as diversas religiões de unidade de todo gênero humano, também capaz de cuidar do planeta e do universo.

\section{Conclusão}

Objetivou-se neste artigo analisar teologicamente a relação entre Igreja e missão, cuja justificativa se encontra na própria identidade mistérico-trinitária da Igreja. Na própria Trindade, encontra-se a missão de cada Pessoa divina, realizada na unidade pericorética inerente à própria substância divina. Disso resulta que, ao possuir origem trinitária, a Igreja é missão e se situa no mundo para realizar a sua missão de evangelizar todos os seres humanos. Essa missão não se realiza sem que a Igreja se situe em cada época histórica, sendo fiel à sua índole e à própria realidade do homem e do mundo.

A missão evangelizadora se efetiva pelas ações eclesiais de anúncio e testemunho da Palavra de Deus, Jesus Cristo, que se fez ser humano, assumiu a história para revelar esse Deus unitrinitário ou triniunitário. Essas ações se configuram na homilia, na catequese, na teologia, em linguagem textual, simbólica e ética, explicitando a relação da Igreja com o mundo em sua época histórica. Ao se inserir no mundo, compreendido em sua epocalidade histórica, a Igreja desenvolve o ecumenismo, a relação com as outras religiões, especialmente o diálogo inter-religioso, e o diálogo com os Estados e a sociedade, de modo a buscar a configuração da justiça, da solidariedade, da cultura do encontro e da paz.

A missão da Igreja, denotativa de sua própria identidade trinitária, não é feita sem a ação do Espírito Santo, que santifica, ilumina. Inspira e impulsiona a Igreja em sua missão. O Espírito é a Pessoa divina que, no movimento da revelação, define-se como ação de Deus na história; ação de irrupção da novidade de Deus na história. Por isso, a evangelização de ser sempre boa notícia a todos os seres humanos, em todas as instâncias de ação evangelizadora. Ao conceber o Espírito como agente evangelizador, a Igreja se conscientiza de seu caráter servidor e concebe a si mesma como sacramento da salvação trazida por Cristo a toda a humanidade. Este Espírito é do Pai Deus e de seu filho Jesus Cristo, o qual chama seres humanos a serem discípulos missionários. Trata-se de que quem evangeliza segue Jesus Cristo ao longo da 
vida e o tem como seu companheiro e amigo. Há,assim, um encontro pessoal com Jesus Cristo, que atinge a profundidade da existência e desperta o amor pelo evangelho e pelo ato de evangelizar. A espiritualidade evangelizadora é a interiorização acerca de que todas as ações evangelizadoras são realizadas pelo Espírito. Nele está a energia amorosa do Filho e do Pai, que impulsiona o discípulo a se animar permanentemente, mesmo em situações difíceis, e a se colocar como membro do povo de Deus, sujeito eclesial e histórico, capaz de peregrinar para ser sinal da salvação traduzida historicamente em unidade, justiça, alegria e paz.

\section{Referências bibliográficas}

ALMEIDA, R. M. “'Deus está morto': A religião na perspectiva de Nietzsche”. In: GONÇALVES, P. SL. (Org.). Um olhar filosófico sobre a religião. Aparecida: Ideias \& Letras, 2012, pp. 51-76.

ANTONCICH, R.; SANS, J. M. M. Ensino Social da Igreja. Petrópolis: Vozes, 1987.

BAUMAN, Z. Modernidade e Ambivalência. Rio de Janeiro: Zahar, 1999.

BAUMAN, Z. O mal-estar da Pós-modernidade. Rio de Janeiro: Zahar, 1998.

BENEDETTI, L. R. "Pós-modernidade: abordagem filosófica". In: GONÇALVES, P. S. L. (Org.). Teologia na Pós-modernidade. Abordagens epistmeológica, sistemática e teórico-prática. São Paulo: Paulinas, 2003, pp. 53-70.

BENTO XVI, PP. “Discurso Inaugural dosa trabalhos da V Conferência Geral do Episcopado da América Latina e do Caribe". In: CELAM. Conferência Geral do Episcopado Latino-americano e Caribenho. São Paulo: Paulus / Paulinas, 2007, pp. 268-269.

CAlEBRESE, G. Per un'Ecclesiologia Trinitaria. Il Mistero di Dio e il Mistero della Chiesa per la Salvezza dell'uomo. Bologna: Edizioni Dehoniane, 2000, pp. 25-68.

CEDRA. Caminhos para a unidade cristã. Pastoral de Ecumenismo. São Paulo: Paulinas, 1987.

CONCÍLIO VATICANO II. "Constituição dogmática Lumen Gentium”. AAS 57 (1965), pp. 5-67. 
CONCÍLIO VATICANO II. "Constituição pastoral Gaudium et Spes". In: Acta Apostolicae Sedis 58 (1966), pp. 1025-1115.

CONCÍLIO VATICANO II. "Decreto Unitatis Redintegratio". In: Acta Apostolicae Sedis 57 (1965), pp. 90-107.

CONFERÊNCIA GERAL DO EPISCOPADO LATINO-AMERICANO. Documento de Aparecida. Texto conclusivo da V Conferência Geral do Episcopado Latino-Americano e do Caribe. São Paulo: Paulus / Paulinas, 2007.

CONGREGAÇÃO PARA A DOUTRINA DA FÉ. "Instrução Libertatis Conscientia”. In: Acta Apostolicae Sedis 79 (1987), pp. 554-599.

DUPUIS, J. Gesú Cristo incontroalle religioni. Assisi: Cittadella Editrice, 1989.

DUPUIS, J. Verso um Teologia Cristiana del pluralismo religioso. Brescia: Queriniana, 1997.

DUQUE, J. M. Par ao diálogo com a Pós-modernidade. São Paulo: Paulus, 2016.

DUQUOC, C. O único Cristo. A sinfonia adiada. São Paulo: Paulinas, 2008.

DUSSEL, E. D. Caminhos de Libertação latino-americana (IV). São Paulo: Paulinas, 1984.

FRANCISCO, PP.; TORNIELLI, A. O nome de Deus é misericórdia. São Paulo: Planeta, 2016.

FRANCISCO, PP. "Exortação Apostólica Evangellii Gaudium". In: Acta Apostolicae Sedis 105 (2013), pp. 1020-1138.

GEFFRÉ, C. Crer e interpretar. Petrópolis: Vozes, 2004.

GEFFRÉ, C. De Babel a Pentecostes. Ensaios de teologia inter-religiosa. São Paulo: Paulus, 2013.

GEFFRÉ, C. Fazer Teologia hoje. São Paulo: Paulus, 1989.

GIRAULT, R. Construire L'Eglise Une. Nouveaux chemins oecuméniques. Paris: Desclée de Brouwer, 1990.

GONÇALVES, P. S. L.; FAVRETTO, A. B. "A liberdade religiosa na Declaração Dignitatis Humanae: elementos para uma nova teologia das religiões e para uma inserção da religião no espaço público". Atualidade Teológica 54 (2016), pp. 664-685. 
GONÇALVES, P. S. L. "A Teologia como ciência ôntica e sua relação com a Filosofia”. Horizonte 35 (2014), pp. 932-956.

GONÇALVES, P. S. L. "A teologia do Concílio Vaticano II e suas consequências na emergência da Teologia da Libertação". In: GONÇALVES, P. S. L.; BOMBONATTO, V. I. Concílio Vaticano II. Análise e prospectivas. São Paulo: Paulinas, 2004, pp. 69-94.

GONÇALVES, P. S. L. "A teologia na cultura pós-moderna”. In: SOUZA, N. Teologia em diálogo. Aparecida/SP: Santuário, 2011.

GONÇALVES, P. S. L. "Cristianismo hoje e amanhã: fé e cultura". In: BINGEMER, M. C.; ANDRADE, P. F. C. (Org.). O mistério e a história. Ensaios de teologia em homenagem ao Pe. Félix Pastor por ocasião dos seus 70 anos. São Paulo: Loyola, 2003, pp. 172-205.

GONÇALVES, P. S. L. "O sonho da unidade dos cristãos. Eclesiologia ecumênica elaborada a partir dos 'princípios católicos' e das comissões mistas. In: BIZON, J.; DRUBI, R. (Org.). A unidade na diversidade. Coletânea de artigos em comemoração aos 40 anos do decreto Unitatis Redintegratio sobre o ecumenismo. São Paulo: Loyola, 2004, pp. 199-241.

GUTIÉRREZ, G. Onde dormirão os pobres. São Paulo: Paulus, 1996.

GUTIÉRREZ, G. La verdad los hara libres. Salamanca: Sal Terrae, 1984.

HAIGHT, R. Jesus, símbolo de Deus. São Paulo: Paulinas, 2003.

HORTAL, J. E haverá um só rebanho. História, doutrina e prática católica do Ecumenismo. São Paulo: Loyola, 1989.

JOÃO PAULO II, PP. “Carta encíclica Sollicitudo Rei Socialis". In: Acta Apostolicae Sedis 80 (1988), pp. 513-586.

JOÃO PAULO II, PP. "Discurso inaugural da III Conferência Geral do Episcopado Latino-americano em Puebla". In: CONFERÊNCIA GERAL DO EPISCOPADO LATINO-AMERICANO. III Conferência Geral do Episcopado Latino-americano. A evangelização no presente e no futuro da América Latina. São Paulo: Loyola, 1982, pp. 24-29.

KASPER, W. A Igreja Católica. Essência, Realidade, Missão. São Leopoldo: Editora Unisinos, 2011. 
KNITTTER, P. F. Introdução às Teologias das Religiões. São Paulo: Paulinas, 2008.

KÜNG, H. A Igreja tem salvação? São Paulo: Paulus, 2012.

KÜNG, H. As religiões do mundo. Em busca dos pontos comuns. Campinas: Vertus, 2004.

MAFFESOLI, M. O Instante Eterno. O retorno do trágico nas sociedades pósmodernas. São Paulo: Zopuk, 2003

MAFFESOLI, M. O ritmo da vida. Variações sobre o imaginário pós-moderno. Rio de Janeiro/São Paulo: Record, 2007.

MIRANDA, M. F. A reforma de Francisco. Fundamentos teológicos. São Paulo: Paulinas, 2017.

NEUNER, P. Ökumenische Theologie. Die Suche nach der Einheit der christlichen Kirchen. Darmstadt: Wissenchaftliche Buchgesellschaft, 1997.

O'COLLINS, G. Fundamental Theology. New York/Mahwah: Paulist Press, 1981.

OLIVEIRA, M. A. A ontologia em debate no pensamento contemporâneo. São Paulo: Paulus, 2014.

OLIVEIRA, M. A. "Pós-modernidade: abordagem filosófica". In: GONÇALVES, P. S. L. Teologia na Pós-modernidade. Abordagens epistemológica, sistemática e teórico-prática. São Paulo: Paulinas, 2003, pp.21-52.

PAULO VI, PP. “Carta encíclica Populorum Progressio". In: Acta Apostolicae Sedis 59 (1967), pp. 257-299.

STAGLIANÒ, A. Il Mistero del Dio Vivente. Per uma teologia dell'Assoluto trinitário. Bologna: Edizioni Dehoniane, 1996, pp. 525-563.

SUESS, P. “Inculturación”. In: ELLACURÍA, I.; SOBRIÑO, J. Mysterium Liberationis. Conceptos fundamentales de la teologia de la liberación. Madrid: Trotta, 1990, pp. 377-422.

SULLIVAN. F. A. Salvation outside the Church? Tracing the History of the Catholic Response. London: Geoffrey Chapman, 1992. 
SUllivAN, F. A. The Church We Believe in. One, Holy, Catholic and Apostolic. New York/Mahwah: Paulist Express, 1988.

TAWARD, G. H. A Igreja, Comunidade de Salvação. Uma eclesiologia ecumênica. São Paulo: Paulus, 1998.

TIEL, G. Ecumenismo na perspectiva do reino de Deus. Uma análise do movimento ecumênico de base. São Leopoldo: Sinodal, 1998.

VON HERMANN, F. W. Die Metaphysik im DenkenHeideggers. Città del Vaticano: Urbaniana, 2004.

Paulo Sérgio Lopes Gonçalves

Doutor em Teologia pela Pontificia Università Gregoriana (Roma)

Docente na Pontifícia Universidade Católica de Campinas

São Paulo/SP - Brasil

E-mail: p_aselogo@hotmail.com

Recebido em: $13 / 12 / 17$

Aprovado em: 11/04/18 